\title{
MulawarmanLawReview
}

\section{The Contradiction of Between Judge's Decision and Legal Provisions Regarding The Position of Heirs in Proof of Land Rights}

\author{
Sulistiani Adont ${ }^{1}$, La Syarifuddin ${ }^{2}$, Rahmawati Al Hidayah ${ }^{3}$ \\ ${ }^{1}$ Alumni of Law Faculty of Mulawarman University, Indonesia. \\ E-mail: sulisadont@gmail.com \\ ${ }^{2}$ Lecturer of Law Faculty of Mulawarman University, Indonesia. \\ E-mail: lasyarifuddin@fh.unmul.ac.id \\ ${ }^{3}$ Lecturer of Law Faculty of Mulawarman University, Indonesia. \\ E-mail: rahma.zee86@gmail.com
}

\begin{abstract}
As the economic development of Indonesian society increases, so will the need for legal certainty in the field of land for the right holder of a plot of land. the fundamental issue in verifying the right to the land is any person claiming to have a right, or appointing an event to affirm his right or to deny any right of another person, shall prove the existence of that right or prove the event, the heirs' a case study of the Samarinda District Court Judgment Number 138 / Pdt.G / 2014 / PN.Smr.

This research uses normative research method. The primary legal material of this research is the legislation that is compiled into a conceptual form based on existing legislation. Which then conducted legal analysis of the problems in this study.

The result of the research is the position of the heirs in verification of the right to land must have at least two evidences, that can prove that the heirs are valid first through the certificate of inheritance. To strengthen the verification of the heirs to the land rights, the heirs must prove by means of evidence as set forth in Article 24 paragraph (1) of Government Regulation Number 24 of 1997 concerning Registration. The second result of the research is the letter of appointment by the Government/Local Government is a valid evidence based on existing legislation, and it becomes the base of the right which is the basis of the land ownership, the analysis of the judge's decision namely the judge decision of Samarinda District Court No. 138 / Pdt.G / 2014 / PN.Smr is incorrect and does not provide legal certainty, it is caused by no reference what is contained in Article 24 paragraph (1) and Article 32 paragraph (2) Government Regulation Number 24 of 1997 on Land Registration
\end{abstract}

Keywords: Decision; Land; Proof; Heir.

Citation: Adont, Sulistiani, La Syarifuddin, and Rahmawati Al Hidayah. 2019. "The Contradiction of Between Judge's Decision and Legal Provisions Regarding The Position of Heirs in Proof of Land Rights". Mulawarman Law Review 3 (2), 133-48. https://doi.org/10.30872/mulrev.v3i2.118. 


\section{INTRODUCTION}

Seiring berkembangnya masyarakat semakin meningkat konflik sengketa tanah yang bermula dari pengaduan berisi keberatan-keberatan dan tuntutan hak atas tanah, baik terhadap status tanah, prioritas maupun kepemilikanya. Semua itu terjadi karena kurangnya bukti kepemilikan atas tanah dan minimnya pengetahuan masyarakat akan arti pentingnya bukti kepemilikan hak atas tanah dalam proses pendaftaran hak atas tanah serta perebutan tanah antar masyarakat dan mengakui hak milik orang lain. Berdasarkan ketentuan dalam Pasal 19 ayat (1) UUPA merupakan ketentuan yang ditujukan kepada pemerintah untuk menyelenggarakan pendaftaran tanah diseluruh Indonesia yang sekaligus juga merupakan dasar hukum bagi pelaksanaan pendaftaran tanah dalam rangka memperoleh surat tanda bukti hak atas tanah yang berlaku sebagai alat pembuktian yang kuat.

UUPA menganut sistem negatif, sehingga keterangan yang tercantum didalam surat bukti hak mempunyai kekuatan hukum dan harus diterima oleh hakim sebagai keterangan yang benar selama dan sepanjang tidak ada alat pembuktian lain yang dapat membuktikan sebaliknya. Jika terjadi hal demikian maka pengadilan akan memutuskan alat pembuktian mana yang benar. Pendaftran tanah tidak menyebabkan mereka yang tidak berhak menjadi berhak atas suatu bidang tanah hanya karena namanya keliru dicatat sebagai yang berhak. Mereka yang berhak dapat menuntut diadakannya pembetulan dan jika tanah yang bersangkutan sudah berada didalam penguasaan pihak ketiga, ia berhak menuntut penyerahan kembali kepadanya ${ }^{1}$.

Persengketaan tanah sangat erat kaitannya dengan pembuktian kebenaran kepemilikan tanah. Pembuktian menurut Riduan Syahrani adalah penyajian alat-alat bukti yang sah menurut hukum kepada hakim yang memeriksa guna memberikan kepastian tentang kebenaran suatu peristiwa yang dikemukakan².

Pengertian pembuktian/membuktikan menurut Sudikno Mertokusumo, terdapat beberapa pengertian antara lain: (1) Membuktikan dalam arti logis atau ilmiah yaitu membuktikan berarti memberikan kepastian yang mutlak, karena berlaku bagi setiap orang dan tidak memungkinkan adanya bukti lawan; (2) Membuktikan dalam arti konvensional membuktikan berarti memberikan kepastian yang nisbi/relatif sifatnya yang mempunyai tingkatan-tingkatan, yaitu Kepastian yang didasarkan atas perasaan belaka/bersifat instutif (conviction intime), Kepastian yang didasarkan atas pertimbangan akal (conviction raisonnee), membuktikan dalam hukum acara mempunyai arti yuridis. ${ }^{3}$ Baik pembuktian yang yuridis maupun yang ilmiah, maka membuktikan pada hakekatnya berarti mempertimbangkan secara logis mengapa peristiwa-peristiwa tertentu dianggap benar, membuktikan dalam arti yuridis tidak lain berarti memberikan dasar-dasar yang cukup kepada hakim yang memeriksa perkara yang bersangkutan guna memberikan kepastian tentang kebenaran peristiwa yang

\footnotetext{
${ }^{1}$ Hasan Kusumah, 1995, Hukum Agraria I, Gremedia Pustaka Utama. Jakarta, Halaman 77

2 Syahrani Riduan, 1998, Hukum Acara Perdata Dilingkungan Peradilan Umum, Pustaka Kartini, Jakarta, halaman 55

${ }^{3}$ Sudikno Martokusumo, 2016, Hukum Acara Perdata Indonesia Edisi Ke 7, Liberti Cet.I, Yokyakarta, halaman 134
} 
diajukan. Berbeda dengan asas yang terdapat pada hukum acara pidana, dimana seseorang tidak boleh dipersalahkan telah melakukan tindak pidana, kecuali apabila berdasarkan bukti-bukti yang sah hakim memperoleh keyakinan tentang kesalahan terdakwa, dalam hukum acara perdata untuk menenangkan seseorang, tidak perlu adanya keyakinan hakim. Hal penting adalah adanya alat-alat bukti yang sah, dan berdasarkan alat bukti tersebut hakim akan mengambil keputusan tentang siapa yang menang dan siapa yang kalah, dengan perkataan lain hukum acara perdata cukup dengan kebenaran formil saja ${ }^{4}$.

Pembuktian, menurut R. Subekti, yang dimaksud dengan membuktikan adalah meyakinkan hakim tentang kebenaran dalil atau dalil-dalil yang dikemukakan dalam suatu persengketaan. Kekuatan pembuktian secara umum kekuatan pembuktian alat bukti tertulis, terutama akta otentik mempunyai tiga macam kekuatan pembuktian yaitu ${ }^{5}$ : (a) Kekuatan pembuktian formil. Membuktikan antara para pihak bahwa mereka sudah menerangkan apa yang ditulis dalam akta tersebut; (b) Kekuatan pembuktian materiil. Membuktikan atara para pihak, bahwa benar-benar peristiwa yang tersebut dalam akta/surat tanah itu telah terjadi; (c) Kekuatan mengikat. Membuktikan antara para pihak dan pihak ketiga, bahwa pada tanggal tersebut dalam akta/surat yang bersangkutan telah menerangkan apa yang ditulis dalam akta tersebut.

Salah satu sengketa tanah yang sampai saat ini masih berlangsung di tingkat kasasi adalah Kasus yang telah terjadi di Jl. Abdul Wahab Syahrani RT. XI, Kelurahan Gunung Kelua, Kecamatan Samarinda Ulu, Kota Samarinda, perkara tersebut terjadi karenakonflik pengakuan hak milik dan bukti kepemilikan hak atas tanah antara HJ. Mujillah selaku penggugatmelawan Kartinah sebagai Tergugat I, H. Bayah sebagai Tergugat II, Cindy Permatasari sebagai Tergugat III, Siswahyono sebagai Tergugat IV, Andika Hasan sebagai Tergugat V, dan Kantor Pertanahan Nasional kota Samarinda selaku Turut Tergugat (Tergugat VI) karena telah menerbitkan Sertipikat diatas Tanah Penggugat. Permasalahan ini bermula dari HJ. Mujillah yang mengajukan gugatan ke Pengadilan Negeri Samarinda pada tanggal 19 Desember 2014 terkait dengan permohonan hak dan penguasaan tanah oleh Kartinah serta penerbitannya Sertipikat Hak Milik oleh BPN di atas tanah tersebut tanpa sepengetahuan dan seijin dari Penggugat.

Apabila seseorang meninggal dunia maka segala hak dan kewajibanya turun, pindah, beralih kepada ahli warisnya. Adapun yang akan beralih kepada ahli warisnya bukan hanya meliputi hak dan kewajiban saja akan tetapi meliputi barang-barang yang berwujud. Sedangkan yang berhak menerima pewarisan adalah suami, istri, anak ataupun orang lain yang ditunjuk.

Meskipun harta waris berpindah dengan sendirinya dari pewaris kepada ahli waris, ketika pewaris meninggal dunia, namun masih dibutuhkan suatu instrument yang

\footnotetext{
${ }^{4}$ Retnowulan S Dan Iskandar O, 2005, Hukum Acara Perdata, P.T Intermasa cet. XXXII, Jakarta, halaman 30

${ }^{5}$ R. Subekti dan R. Tjitrosudibio, 2005, Kitab Undang-undang Hukum Perdata, PT Pradnya Paramita Cet. XXV, Jakarta, halaman 475
} 
dapat digunakan sebagai suatu alat bukti yang dapat menunjukkan bahwa seseorang adalah benar orang yang berhak atas suatu harta waris. Hal itu dikarenakan harta waris yang berupa tanah memerlukan proses pendaftaran hak apabila terjadi peralihan hak yang disebabkan oleh pewarisan. ${ }^{6}$

Penggugat adalah salah satu ahli waris (istri) dari almarhum H. Muhammad Ilham yang meninggal dunia tanggal 6 Oktober 2007 dibuktikan dengan surat keterangan ahli waris tertanggal 22 Maret 2010 Nomor 593/245/423.402.07/2010, diketahui oleh Lurah Purworejo dan Camat Porworejo Kota Pasuruan Jawa Timur dan di buktikan dengan Surat Nikah Nomor 85/1973 tertanggal 18 Januari 1973 M yang dikeluarkan oleh Dinas Urusan Agama Banjarmasin. Semasa hidup Almarhum mempunyai tanah perwatasan seluas kurang lebih $22.030 \mathrm{M} 2$ (dua puluh dua ribu tiga puluh meter persegi) terletak dahulu dijalan Pandan Wangi Kecamatan Samarinda Ulu, Kotamadya Samarinda, sekarang dikenal Jalan Abdul Wahab Syahrani. Berdasarkan Surat Penunjukan dari Walikotamadya Kepala Daerah Tingkat II Samarinda sekarang disebut Walikota Samarinda tanggal 18 November 1980 Nomor 48/SP/Komas/1980 dengan lampiran Gambar Situasi (GS) Nomor 1543/K/80 tanggal 23 September 1980, tanah tersebut diperoleh sebagai penggantian atas tanah kaplingan yang terkena perluasan Univeritas Mulawarman (UNMUL) di Jalan M. Yamin Gunung Kelua pada tahun 1980 untuk menempati tanah seluas $22.030 \mathrm{M}^{2}$ yang terletak di Jalan Pandan Wanggi, sekarang di kenal dengan Jalan Abdul Wahab Syahrani .

Tanggal 27 Agustus 1992, sebagian dari tanah tersebut seluas kurang lebih 8.432 M2 dilepaskan oleh Almarhum kepada saudara M. Muryadi, kemudian tanggal 20 April 1995 sebagian lagi dilepaskan kepada Sdr. David Efendi seluas kurang lebih $4.415 \mathrm{M}^{2}$, selanjutnya tanggal 21 April 1998 sebagian lagi di lepaskan kepada Yayat Supriatna seluas Kurang lebih $1.000 \mathrm{M}^{2}$ serta $700 \mathrm{M}^{2}$ dilepaskan kepada Kadmidi. Sehingga sisa tanah Penggugat adalah seluas kurang lebih $7.483 \mathrm{M}^{2}$. Tanggal 22 Desember 2009 atas permohonan dari Penggugat kepada Badan Pertanahan Nasional, dilakukan pengembalian batas atas tanah objek berdasarkan Gambar Situasi Nomor 1543/1980 tanggal 23 September 1980 (Lampiran Surat Penunjukan Walikotamadya Samarinda tertanggal 18 Nopember Nomor 48/SP/Komas/1980) diketahui secara pasti bahwa diatas tanah sisa yang seluas kurang lebih $7.483 \mathrm{M}^{2}$ tersebut sebagian besar telah dikuasai oleh pihak ketiga tanpa seijin dan sepengetahuan Penggugat dan dari hasil pengengembalian batas tersebut diketahui pula bahwa ternyata di atas sisa tanah Penggugat tersebut sebagian yaitu seluas $1.174 \mathrm{M}^{2}$ telah dimohonkan hak oleh Tergugat I dan telah diterbitkan Sertipikat Hak Milik (SHM) Nomor 1147 Kelurahan Air Putih tahun 1986 atas nama Ny. Kartinah sebagai pemegang Hak Milik. Sertipikat Hak Milik Nomor 1147 Kelurahan Air Putih pada saat pengembalian batas adalah tercatat atas nama Cindy Permatasari/tergugat III. Tanah objek sengketa dari awal memang ingin digunakan sendiri oleh Penggugat karena letaknya dipinggir jalan utama, akan tetapi waktu itu belum ramai penduduk sehingga belum didirikan bangunan dan pada saat itu Almarhum suami Penggugatyang berpropesi sebagai Pegawai Negeri Sipil

\footnotetext{
${ }^{6}$ RM Pramana, 2014. Analisis Yuridis Surat Keterangan Waris Sebagai Alat Bukti. studentjournal.ub.ac.id. https://media.neliti.com/media/publications/34936-ID-analisis-yuridis-surat-keterangan-waris-sebagaialat-bukti.pdf . Di akses 8 Juni 2018, pk. 11.34 Wite
} 
dipindahkan ke Pulau Jawa jadi objek tersebut ditinggalkan.Namun setelah perkembangan kota samarinda tanah tersebut justru dikuasai oleh pihak lain, pada tahun 2009 obyek tersebut sudah dikuasai oleh Tergugat III yang digunakan sebagai Showroom Jual Beli Mobil.Tanggal 09 juni 2010 Sertipikat Hak Milik (SHM) mengalami perubahan, yang dahulu Sertipikat Hak Milik Nomor 1147 Kelurahan Air Putih Kecamatan Samarinda, SU : 1988/1986 berubah menjadi Sertipikat Hak Milik Nomor 1134 Kelurahan Gunumg Kelua Kecamatan Samarinda Ulu Kota Samarinda, SU : 139/2010, NIB : 16010308.1.01980, dengan luas tanah tetap seluas $1.174 \mathrm{M}^{2}$ terletak dahulu jalan Pandan Harum sekarang jalan AW. Syahrani RT. XI Kelurahan Gunung Kelua, Kecamatan Samrina Ulu Kota Samarinda

Berdasarkan data pencatatan peralihan hak pada sertipikat hak milik diketahui Tergugat III membeli tanah sengketa dari Tergugat Ilpada tanggal 9 April 1998, demikian pula Tergugat II membeli dari Tergugat Ipada tanggal 11 Februari 1995. Bahwa oleh karena tanah obyek sengketa yang dimohonkan hak oleh Tergugat I adalah merupakan bagian dari tanah hak Penggugat yang diperoleh dari Penunjukan Walikota Samarinda tahun 1980, pada tanggal 1 Desember 2010 melalui mediasi oleh Tergugat VI (BPN), dicapai kesepakatan penyelesaian masalah tanah yang dikuasai Tergugat III dengan konpensasi sebesar Rp. 587.000.000;- dari Tergugat III kepada Penggugat, namun tanpa alasan yang jelas kesepakatan tersebut dibatalkan oleh Tergugat III tanggal 10 Februari 2011. Pada tahun yang sama Tergugat III justru menjual tanah obyek sengketa tersebut kepada Tergugat IV, yang selanjutnya Tergugat IV menjual lagi tanah tersebut kepada Tergugat V.

Atas terbitnyaSertipikat Hak MilikNomor : 1134/Kel. Gunung Kelua yang telah diterbitkan Tergugat $\mathrm{VI}$ di atas tanah hak Penggugat, padahal Tergugat VI mengetahui atau patut mengetahui kalau sejak tahun 1980 tanah tersebut telah menjadi hak Almarhum M. Ilham/Penggugatberdasarkan Surat Penunjukan Walikota Samarinda tanggal 18 November 1980 Nomor : 48/SP/Komas/1980 dengan lampiran Gambar Situs (GS) Nomor : 154/K/80 tanggal 23 September 1980 yang di buat oleh Tergugat VI.

Berdasarkan putusan Pengadilan Negeri Samarinda Nomor 138/Pdt.G/2014/PN.Smr pada tanggal 01 Oktober 2015 Majelis Hakim memutuskan menolak gugatan Penggugat dengan alasan bukti-bukti yang diajukan Penggugat tidak mendukung dalildalil gugatanya bahkan bertentangan antara satu dan yang lainya dan tidak dapat memberikan bukti-bukti yang dapat dipertanggungjawabkan serta tidak memberikan dasar hukum untuk dianalisa kebenanaranya.Kerena merasa kecewa dengan Putusan Pengadilan Negeri Penggugat mengajukan upaya hukum ditinggkat banding ke Pengadilan Tinggi Negeri Samarinda dan memperoleh hasil yang memuaskan banding yang dimohonkan dikabulkan oleh Pengadilan Negeri Tinggi Samarinda Nomor 34/PDT/2016/PT.Smr yang mengabulkan gugatan Penggugat dan membenarkan buktibukti kepemilikan atas tanah yang dimiliki oleh Penggugat.

Pembuktian bersifat historis, dalam arti apa yang hendak dibuktikan dalam suatu persengketaan merupakan suatu yang sudah terjadi atau menerangkan apa yang telah terjadi secara nyata/inconcrete, sehingga suatu peristiwa dan hubungan hukumnya dapat ditetapkan. Dalam sengketa tanah alat bukti untuk membuktikan obyek hak atas tanah telah ditentukan untuk memberikan kepastian hukum bagi pemilik hak, dan 
pembuktian itu dapat dilakukan oleh ahli waris terhadap obyek tanah yang belum dilakukan pendaftaran tanah oleh pewaris. Maka tulisan ini mengkaji Kekuatan kedudukan Pembuktian Hak Atas Tanah Dari Ahli Waris, serta Analisis Hukum Terhadap Putusan Pengadilan Negeri Nomor: 138/Pdt.G/2014/PN.Smr.

\section{METHOD}

Jenis Penelitian adalah penelitian normatif, yang ditujukan untuk menganalisis kedudukan hukum ahli waris dalam pembuktian hak atas tanah dalam persidangan. Menurut Peter Mahmud Marzuki, penelititian hukum normatif adalah proses untuk menemukan suatu aturan hukum, prinsip-prinsip hukum, serta doktrin-doktrin hukum guna menjawab isu hukum yang dihadapi. ${ }^{7}$ Oleh karena penelitian yang dilakukan oleh penulis adalah untuk menganalisis kedudukan hukum dari ahli waris dalam pembuktian hak atas tanah sebagaimana terdapat dalam Putusan Pengadilan Negeri Samarinda Nomor: 138/Pdt.G/2014/PN.Smr dan putusan tersebutlah yang menjadi objek penelitian maka tepat penelitian ini digolongkan sebagai penelitian normatif.

\section{DISCUSSION}

Pokok Perkara dalam Putusan Pengadilan Negeri Samarinda Nomor: 138/Pdt.G/2014/PN.Smr

Duduk Perkara dalam perkara Nomor: 138/Pdt.G/2014/PN.Smr adalah Bahwa Penggugat adalah salah satu Ahli Waris (istri) dari Almarhum H Muhamad Ilham alias M. Ilham meninggal dunia tanggal 6 Oktober 2007. Bahwa semasa hidup Almarhum $\mathrm{H}$. Muhamad Ilham, S.E ada mempunyai tanah perwatasan seluas $\pm 22.030 \mathrm{M}^{2}$ (dua pulu dua ribu tiga puluh meter persegi) terletak dahulu di Jalan Pandan Wangi Kecamatan Samarinda Ulu, Kotamadya Samarinda, sekarang dikenal Jalan Abdul Wahab Syahrani RT. XI Kelurahan Gunung Kelua, Kecamatan Samarinda Ulu, Kota Samarinda, ukuran dan batas-batas tanah sebagaimana tersebut dalam Gambar Situasi Nomor 154/K/80 tanggal 23 Nopember 1980 yang dibuat oleh Tergugat IV/Turut Tergugat.

Tanah tersebut Penggugat peroleh sebagai penggantian atas tanah kaplingan Penggugat yang terkena perluasan UNMUL (Universitas Mulawarman) di Jalan M. Yamin (Gunung Kelua) tahun 1980. Berdasarkan Surat Penunjukan dari Walikotamadya Samarinda Tk. II sekarang disebut Walikota Samarinda tertanggal 18 November 1980 No. 48/SP/Komas/1980 dengan lampiran Gambar Situasi (GS) No. 1543/K/80 tanggal 23 September 1980, untuk menepati tanah seluas $22.030 \mathrm{M}^{2}$ terletak di Jalan Pandan Wangi Kecamatan Samarinda Ulu kotamadya Samarinda, sekarang dikenal Jalan Abdul Wahab Syahrani Kelurahan Gunung Kelua, Kecamatan Samarinda Ulu, Kota Samarinda.

Tanggal 27 Agustus 1992, sebagian dari tanah tersebut seluas kurang lebih 8.432 M2 dilepaskan oleh Almarhum kepada saudara M. Muryadi, kemudian tanggal 20 April 1995 sebagian lagi dilepaskan kepada Sdr. David Efendi seluas kurang lebih $4.415 \mathrm{M}^{2}$, selanjutnya tanggal 21 April 1998 sebagian lagi di lepaskan kepada Yayat Supriatna

\footnotetext{
${ }^{7}$ Peter Mahmud Marzuki, 2010, penelitian hukum, Jakarta: Kencana, halaman 35
} 
seluas Kurang lebih $1.000 \mathrm{M}^{2}$ serta $700 \mathrm{M}^{2}$ dilepaskan kepada Kadmidi. Sehingga sisa tanah Penggugat adalah seluas kurang lebih $7.483 \mathrm{M}^{2}$.

Tanggal 22 Desember 2009 atas permohonan dari Penggugat kepada Badan Pertanahan Nasional, dilakukan pengembalian batas atas tanah objek berdasarkan Gambar Situasi Nomor 1543/1980 tanggal 23 September 1980 (Lampiran Surat Penunjukan Walikotamadya Samarinda tertanggal 18 Nopember Nomor 48/SP/Komas/1980) diketahui secara pasti bahwa diatas tanah sisa yang seluas kurang lebih $7.483 \mathrm{M}^{2}$ tersebut sebagian besar telah dikuasai oleh pihak ketiga tanpa seijin dan sepengetahuan Penggugat dan dari hasil pengengembalian batas tersebut diketahui pula bahwa ternyata di atas sisa tanah Penggugat tersebut sebagian yaitu seluas $1.174 \mathrm{M}^{2}$ telah dimohonkan hak oleh Tergugat I dan telah diterbitkan Sertipikat Hak Milik (SHM) Nomor 1147 Kelurahan Air Putih tahun 1986 atas nama Ny. Kartinah sebagai pemegang Hak Milik. Sertipikat Hak Milik Nomor 1147 Kelurahan Air Putih pada saat pengembalian batas adalah tercatat atas nama Cindy Permatasari/tergugat III. Tanggal 09 juni 2010 Sertipikat Hak Milik (SHM) mengalami perubahan, yang dahulu Sertipikat Hak Milik Nomor 1147 Kelurahan Air Putih Kecamatan Samarinda, SU : 1988/1986 berubah menjadi Sertipikat Hak Milik Nomor 1134 Kelurahan Gunumg Kelua Kecamatan Samarinda Ulu Kota Samarinda, SU : 139/2010, NIB : 16010308.1.01980, dengan luas tanah tetap seluas $1.174 \mathrm{M}^{2}$ terletak dahulu jalan Pandan Harum sekarang jalan AW. Syahrani RT. XI Kelurahan Gunung Kelua, Kecamatan Samrina Ulu Kota Samarinda.

Berdasarkan data pencatatan peralihan hak pada sertipikat hak milik diketahui Tergugat III membeli tanah sengketa dari Tergugat II pada tanggal 9 April 1998, demikian pula Tergugat II membeli dari Tergugat I pada tanggal 11 Februari 1995. Bahwa oleh karena tanah obyek sengketa yang dimohonkan hak oleh Tergugat I adalah merupakan bagian dari tanah hak Penggugat yang diperoleh dari Penunjukan Walikota Samarinda tahun 1980, maka penguasaan Tergugat I atas obyek sengketa merupakan perbuatan melawan hukum dengan segala akibat hukumnya, demikian pula perbuatan Tergugat I yang menjual obyek sengketa kepad Tergugat II, selanjutnya Tergugat II menjual lagi kepada Tergugat III adalah merupakan perbuatan melawan hukum dan jual beli atas tanah obyek sengketa tersebut harus dibatalkan atau dinyatakan batal demi hukum.

Bahwa pada tanggal 1 Desember 2010 melalui mediasi oleh Tergugat VI (BPN), dicapai kesepakatan penyelesaian masalah tanah yang dikuasai Tergugat III dengan konpensasi sebesar Rp. 587.000.000;- dari Tergugat III kepada Penggugat, namun tanpa alasan yang jelas kesepakatan tersebut dibatalkan oleh Tergugat III tanggal 10 Februari 2011. Pada tahun yang sama Tergugat III justru menjual tanah obyek sengketa tersebut kepada Tergugat IV, yang selanjutnya Tergugat IV menjual lagi tanah tersebut kepada Tergugat $\mathrm{V}$ adalah perbuatan melawan hukum.

Bahwa oleh karena perbuatan Tergugat I samapai dengan tergugat $\mathrm{V}$ yang menjual belikan tanah hak Penggugat tersebut secara melawan hukum, maka sangat beralasan menurut hukum untuk menyatakan jual beli atas tanah obyek sengketa (SHM No. 1134/Kel. Gunung Kelua) tersebut dari Tergugat I Kepada Tergugat II, Kemudian dari Tergugat II kepada Tergugat III, selanjutnya dari Tergugat III kepada Tergugat VI 
terakhir dari Tergugat IV kepada Tergugat $\mathrm{V}$ adalah harus dinyatakan batal demi hukum.

Bahwa oleh karena Sertipikat Hak Milik No. 1134/Kel. Gunung Kelua tersebut telah diterbitkan oleh Tergugat VI diatas tanah Penggugat, Padahal Tergugat VI mengetahui atau patut mengetahui kalau sejak tahun 1980 tanah tersebut telah menjadi hak milik Alm. M. Ilham/Penggugat berdasarkan surat penunjukan dari Wali Kota Samarinda tertanggal Samarinda tanggal 18 November 1980 Nomor : 48/SP/Komas/1980 dengan lampiran Gambar Situs (GS) Nomor : 154/K/80 tanggal 23 September 1980 yang di buat oleh Tergugat VI tersebut dinyatakan perbuatan melawan hukum oleh Penguasa dan sangat beralasan pula menyatakan Sertipikat Hak Milik No. 1134/Kel. Gunung Kelua tersebut tidak mempunyai kekuatan hukum tetap.

Penggugat mengajukan gugatan secara tertulis pada tanggal 19 Desember 2014 yang telah didaftarkan di Kepanitraan Pengadilan Negeri Samarinda pada tanggal 23 Desember 2014 di bawah Register Nomor: 138/Pdt.G/2014/PN.Smr kepada tergugat dan turut tergugat. Berdasarkan putusan Pengadilan Negeri Nomor 138/Pdt.G/2014/PN.Smr pada tanggal 01 Oktober 2015 Majelis Hakim memutuskan menolak gugatan Penggugat dengan alasan bukti-bukti yang diajukan Penggugat tidak mendukung dalil-dalil gugatanya bahkan bertentangan antara satu dan yang lainya dan tidak dapat memberikan bukti-bukti yang dapat dipertanggungjawabkan serta tidak memberikan dasar hukum untuk dianalisa kebenanaranya. Karena merasa kecewa dengan Putusan Pengadilan Negeri Penggugat mengajukan upaya hukum ditinggkat banding ke Pengadilan Tinggi Negeri Samarinda dan memperoleh hasil yang memuaskan banding yang dimohonkan dikabulkan oleh Pengadilan Negeri Tinggi Samarinda Nomor 34/PDT/2016/PT.Smr yang mengabulkan gugatan Penggugat dan membenarkan bukti-bukti kepemilikan atas tanah yang dimiliki oleh Penggugat.

\section{Kekuatan Kedudukan Pembuktian Hak Atas Tanah Dari Ahli Waris}

Pendaftaran atas bidang tanah dilakukan agar mendapatkan kepastian hukum bagi pemegang hak atas tanah maupun pihak lain yang berkepentingan dengan tanah. Dengan telah melakukan pendaftaran dan mendapatkan sertipikat, pemegang hak atas tanah memiliki bukti yang kuat atas tanah tersebut. Undang-Undang Pokok Agraria mengatur bahwa Pemerintah mengadakan pendaftaran Tanah di seluruh wilaya Republik Indonesia yang bertujuan untuk menjamin kepastian Hukum atas hak-hak atas tanah. ${ }^{8}$

Dinyatakan juga fungsi sertipikat dalam Pasal 19 ayat (2) huruf c UUPA, karena itu, siapapun dapat dengan mudah membuktikan dirinya sebagai pemegang hak atas tanah bila telah jelas namanya tercantum dalam sertipikat itu. Selanjutnya dapat membuktikan mengenai keadaan-keadaan dari tanahnya itu misalnya luas, batasbatas, ataupun segala sesuatu yang berhubungan dengan bidang tanah dimaksud. Sejalan dengan itu kitab undang-undang hukum perdata juga nenyatakan dalam pasal 1865 dan pasal 1866 tentang pembuktian pada umumnya yang berbunyi : setiap orang

\footnotetext{
8 Urip Santoso., Pendaftaran dan Peralihan Hak atas Tanah., Prenada Media Group, Jakarta 2010, cetakan ke-2, hal 248.
} 
yang mendalikan bahwa ia mempunyai sesuatu haak,atau guna meneguhkan haknya sendiri mupun membantu suatu hak orang lain,menunjuk pada suatu peristiwa, diwajibkan membuktikan adanya hak atau peristiwa tersebut dengan alat-alat buki yang terdiri atas : bukti tulisan, bukti dengan saksi-saksi, persangkaan-persangkaan, pengakuan, sumpah dan segala sesuatu dengan mengindahkan aturan-aturan yang ditetapkan. ${ }^{9}$

Terdapat tiga (3) teori yang menjelaskan tentang sampai berapa jauhkah hukum positisf dapat mengikat hakim atau para pihak dalam pembuktian peristiwa didalam sidang, yaitu ${ }^{10}$ : (a) Teori pembuktian bebas. Teori ini tidak menghendaki adanya ketentuan-ketentuan yang mengikat hakim, sehingg penilaian pembuktian seberapa dapat diserahkan kepada hakim. Teori ini dikehendaki jumhur/pendapat umum karena akan memberikan kelonggaran wewenang kepada hakim dalam mencari kebenaran; (b) Teori pembuktian negatif. Teori ini hanya menghendaki ketentuan-ketentuan yang menagatur larangan-larangan kepada hakim untuk melakukan sesuatu yang berhubungan dengan pembuktian. Jadi hakim disini dilarang dengan pengecualian (ps.169 HIR,306 Rbg, 1905 BW); (c) Teori pembuktian positif. Disamping adanya larangan, teori ini menghendaki adanya perintah kepada hakim. Disini hakim diwajibkan, tetapi dengan syarat (ps.165 HIR, 285 Rbg, 1870 BW).

Menurut undang-undang Pasal 164 HIR, 284 Rbg, 1866 BW, ada 5 (lima) macam alat pembuktian yang sah, yaitu bukti tertulis, kesaksian, persangkaan, pengakuan, sumpah. Berikut ini urian-urian secara singkat tentang alat bukti, yaitu Pertama: Bukti tertulis yaitu surat, surat adalah salah satu bukti tertulis menurut undang-undang, surat-surat dapat dibagi dalam surat akte dan surat-surat lain. Surat akte ialah suatu tulisan yang semata-mata dibuat untuk membuktikan suatu hal maupun peristiwa, karenanya suatu akta harus selalu ditandatangani. Surat-surat akta dapat dibagi lagi atas akta resmi (authentiek) dan surat akte dibawah tangan (onderhands). Suatu akta resmi (authentiek) ialah suatu akta yang dibuat oleh suatu akta yang dibuat oleh atau dihadapan pejabat umum yang menurut undang-undang ditugaskan untuk membuat surat-surat akta tersebut. Suatu akta dibawah tangan (onderhands) ialah tiap akta yang tidak dibuat oleh atau dengan perantara seorang pejabat umum. Misalnya, surat perjanjian jual-beli atau sewa menyewa yang dibuat sendiri dan ditandatangani sendiri oleh kedua belah pihak yang mengadakan perjanjian itu ${ }^{11}$. Pejabat umum yang dimaksud adalah Notaris, Hakim, Jurusita, Pada Suatu Pengadilan, Pegawai Pencatatan Sipil (Ambtennaar Burgelijke Stand), dan sebagainya yang kekuatan pembuktianya diserahkan kepada pertimbngan hakim, hakim leluasa untuk mempercayai atau tidak mempercayai kebenaran ${ }^{12}$.

Alat bukti kedua: Kesaksian, sesudah pembuktian dengan tulisan, pembuktian dengan kesaksian merupakan cara pembuktian yang terpenting dalam perkara yang sedang diperiksa didepan hakim. Suatu kesaksian, harus menganai peristiwa-peristiwa yang

\footnotetext{
9 .R.Subekti,S.H. dan R.Tjitrosudibio.,kitab Undang-Undang Hukum Perdata., Pradnya Paramita, Jakarta 2008. Hal 475

10 R. Subekti, 1995, Hukum Pembuktian, PT. Pradnya Paramita, halaman 37

${ }^{11}$ lbid

${ }^{12}$ lbid
} 
yang dilihat dengan mata sendiri atau yang dialami sendiri oleh seorang saksi ${ }^{13}$. Jadi tidak boleh saksi itu hanya mendengar saja tentang adanya peristiwa dari orang lain. Kesaksian bukanlah alat pembuktian yang sempurna dan mengikat hakim, tetapi terserah pada hakim untuk menerimanya atau tidak. Artinya, sehingga minimal dua orang saksi (unus testis ulus testis) harus dipenuhi atau ditambah alat bukti lain. Artinya, hakim tidak boleh mendasarkan putusan tentang kalah menangnya suatu pihak atas keterangan satu saksi saja.

Kesaksian adalah kepastian yang diberikan kepada hakim dipersidangan tentang peristiwa yang dipersengketakan dengan jalan pemberitahuan secara lisan dan pribadi ileh orang yang bukan salah satu pihak berperkara, yang dipanggil dalam persidangan. Jadi keterangan yang diberikan oleh seorang saksi haruslah kejadian yang telah ia alami sendiri, sedangkan pendapat atau dugaan yang diperoleh secara berpikir tidaklah termasuk dalam suatu kesaksian, kesaksian itu harus selalu ditambah dengan suatu alat pembuktian lain ${ }^{14}$.

Menurut M. Yahya Harahap menyatakan bahwa alat bukti (bewijsmiddel) adalah suatu hal berupa bentuk dan jenis yang dapat membantu dalam hal memberi keterangan dan penjelasan tentang sebuah masalah perkara untuk membantu penilaian hakim didalam pengadilan. Jadi, para pihak yang berperkara hanya dapat membuktikan kebenaran dalil gugat dan dalil bantahan maupun fakta-fakta yang mereka kemukakan dengan jenis atau bentuk alat bukti tertentu. Pembuktian tidak selalu pihak penggugat saja yang harus membuktikan dalilnya. Hakim yang memeriksa perkara yang akan menentukan siapa diantara pihak-pihak yang berperkara yang akan diwajibkan memberi bukti, apakah pihak penggugat atau sebaliknya pihak tergugat.

Secara ringkas dikaitkan bahwa hakim sendiri yang menentukan pihak yang akan membuktian, hakim harus bertindak arif dan bijaksana dalam mengambil keputusan, serta tidak boleh berat sebelah dan hakim harus bertindak adil kepada semua pihak. Semua pedoman, dijelaskan oleh Pasal 1865 BW, bahwa: "Barang siapa mengajukan peristiwa-peristiwa atas nama dia mendasarkan suatu hak, diwajibkan membuktikan peristiwa-peristiwa itu, sebaliknya barang siapa mengajukan peristiwa-peristiwa guna membantah hak orang lain, diwajibkan juga membuktikan peristiwa-peristiwa itu".

Kekuatan Sertipikat dalam Pembuktian Hak Atas Tanah. Pendaftaran atas bidang tanah dilakukan agar mendapatkan kepastian hukum bagi pemegang hak atas tanah maupun pihak lain yang berkepentingan dengan tanah. Dengan telah melakukan pendaftaran dan mendapatkan sertipikat, pemegang hak atas tanah memiliki bukti yang kuat atas tanah tersebut.

Undang-Undang Pokok Agraria mengatur bahwa Pemerintah mengadakan pendaftaran Tanah di seluruh wilaya Republik Indonesia yang bertujuan untuk menjamin kepastian Hukum atas hak-hak atas tanah. Dinyatakan juga fungsi sertipikat dalam Pasal 19 ayat (2) huruf c UUPA, karena itu, siapapun dapat dengan mudah membuktikan dirinya sebagai pemegang hak atas tanah bila telah jelas namanya tercantum dalam sertipikat

\footnotetext{
${ }^{13} \mathrm{Ibid}$

${ }^{14}$ Mertokusumo Sudikno, 2006, Hukum Acara Perdata Indonesia, Liberty Yokyakarta, halaman 161
} 
itu. Selanjutnya dapat membuktikan mengenai keadaan-keadaan dari tanahnya itu misalnya luas, batas-batas, ataupun segala sesuatu yang berhubungan dengan bidang tanah dimaksud. Sejalan dengan itu kitab undang-undang hukum perdata juga nenyatakan dalam pasal 1865 dan pasal 1866 tentang pembuktian pada umumnya yang berbunyi : setiap orang yang mendalikan bahwa ia mempunyai sesuatu haak,atau guna meneguhkan haknya sendiri mupun membantu suatu hak orang lain,menunjuk pada suatu peristiwa, diwajibkan membuktikan adanya hak atau peristiwa tersebut dengan alat-alat buki yang terdiri atas : bukti tulisan, bukti dengan saksi-saksi, persangkaan-persangkaan, pengakuan, sumpah dan segala sesuatu dengan mengindahkan aturan-aturan yang ditetapkan. Apabila dikemudian hari terjadi tuntutan hukum di pengadilan tentang hak kepemilikan/penguasaan atas tanah, maka semua keteranagan yang dimuat dalam sertipikat hak atas tanah itu mempunyai kekuatan pembuktian yang kuat dan karenanya hakim harus menerima sebagai keterangan-keterangan yang benar, sepanjang tidak ada bukti lain yang mengingkarinya atau membuktikan sebaliknya.

Tetapi jika ternyata ada kesalahan didalamnya, maka diadakan perubahan / pembetulan seperlunya. Dalam hal ini yang berhak melakukan pembetulan bukanlah pengadilan melainkan instansi yang menerbitkannya yakni Badan Pertanahan Nasional (BPN) dengan jalan pihak yang dirugikan mengajukan permohonan perubahan sertipikat dengan melampirkan surat keputusan pengadilan yang menyatakan adanya kesalahan dimaksud.Kajian mengenai kekuatan berlakunya sertipikat sangat penting, karena sertipikat memberikan kepastian hukum pemilikan tanah bagi Orang yang namanya tercantum dalam sertipikat Pemilik sertipikat merasa tenang dan tentram karena dilindungi dari tindakan sewenang-wenang oleh siapapun, serta penerbitan sertipikat dapat mencegah sengketa tanah.

Dengan adanya sertipikat pemilik hak atas tanah tersebut dapat melakukan perbuatan hukum apa saja sepanjang tidak bertentangan dengan undang-undang, ketertiban umum, dan kesusilaan. Selain itu juga sertipikat mempunyai nilai ekonomi yang tinggi apabila dijadikan jaminan utang (sala satu Fungsi Sertipikat). Menurut Undang-Undang Pokok Agraria sebagai landasan hukum bidang pertanahan di Indonesia, Pasal 19 ayat (2) sub c sertipikat sebagai alat pembuktian yang kuat. Pengertian dari sertipikat sebagai alat pembuktian yang kuat adalah bahwa data fisik dan yuridis yang sesuai dengan data yang tertera dalam Buku Tanah dan Surat Ukur yang bersangkutan harus dianggap sebagai data yang benar kecuali dibuktikan sebaliknya oleh pengadilan. Sehingga selama tidak bisa dibuktikan sebaliknya, data fisik dan data yuridis yang tercantum didalamnya harus diterima sebagai data yang benar, baik dalam melakukan perbuatan hukum sehari-hari, maupun dalam berperkara dipengadilan, sehingga data yang tercantum benar-benar harus sesuai dengan surat ukur yang bersangkutan, karena data yang diambil berasal dari surat ukur dan buku tanah tersebut. 


\section{Analisis Hukum Terhadap Putusan Pengadilan Negeri Nomor: 138/Pdt.G/2014/PN.Smr}

Analisa atas kekuatan alat bukti berupa Surat Penunjukan Walikotamadya Kepala Daerah Tk. II Samarinda Nomor: 48/SP/Komas/1980 tanggal 18 November 1980. Berdasarkan Surat Penunjukan dari Walikotamadya Kepala Daerah Tingkat II Samarinda sekarang disebut Walikota Samarinda tanggal 18 November 1980 Nomor 48/SP/Komas/1980 dengan lampiran Gambar Situasi (GS) Nomor 1543/K/80 tanggal 23 September 1980, surat ini menjadi dasar pihak penggugat untuk membuktikan hak atas tanah tersebut diperoleh sebagai penggantian atas tanah kaplingan yang terkena perluasan Univeritas Mulawarman (UNMUL) di Jalan M. Yamin Gunung Kelua pada tahun 1980, untuk menempati tanah seluas $22.030 \mathrm{M}^{2}$ yang terletak di Jalan Pandan Wanggi, sekarang di kenal dengan Jalan Abdul Wahab Syahrani.${ }^{15}$

Dalam putusan nomor 138/Pdt.G/2014/PN.Smr, pembuktian yang diajukan oleh penggugat dinyatakan tidak dapat dijadikan dasar yang membuktikan bahwah penggugat sebagai ahli waris yang berhak atas tanah yang menjadi obyek sengketa tersebut. Putusan hakim tersbut kemudian yang menjadi dasar untuk menolak gugatan penggugat. Pada Pasal 32 ayat (2) dapat dilakukan gugatan atas seritifkat hak atas tanah selama tidak lebih dari 5 (lima) tahun sejak sertipikat itu diterbitkan.

Pada Pasal 32 ayat (2) dapat dilakukan gugatan atas seritifkat hak atas tanah selama tidak lebih dari 5 (lima) tahun sejak sertipikat itu diterbitkan. putusan hakim Pengadilan Negeri Samarinda Nomor 138/Pdt.G/2014/PN.Smr tidaklah tepat dan tidak memberikan kepastian hukum, hal itu disebabkan oleh tidak dijadikan rujukan apa yang termuat dalam Pasal 24 ayat (1) dan Pasal 32 ayat (2) Peraturan Pemerintah Nomor 24 Tahun 1997 tentang Pendaftaran Tanah.

Surat penunjukan sebagai alat bukti dapat kita temukan dalam Peraturan Pemerintah Nomor 24 Tahun 1997 tentang Pendaftaran Tanah, dalam Pasal 24 ayat (1) disebutkan bahwa "Untuk keperluan pendaftaran hak, hak atas tanah yang berasal dari konversi hak-hak lama dibuktikan dengan alat-alat bukti mengenai adanya hak tersebut berupa bukti-bukti tertulis, keterangan saksi dan atau pernyataan yang bersangkutan yang kadar kebenarannya oleh Panitia Ajudikasi dalam pendaftaran tanah secara sistematik atau oleh Kepala Kantor Pertanahan dalam pendaftaran tanah secara sporadik, dianggap cukup untuk mendaftar hak, pemegang hak dan hak-hak pihak lain yang membebani-nya". Kemudian dalam bagian penjelasan Pasal 24 ayat (1) tersebut dirincikan alat bukti tersebut dapat berupa surat penunjukan atau pembelian kaveling tanah pengganti tanah yang diambil oleh Pemerintah atau Pemerintah Daerah. Artinya dapat kita analisa bahwa surat penunjukan yang kemudian dikeluarkan oleh pemerintah atau pemerintah dasar merupakan alat bukti atas kepemilikan tanah yang sah dan diakuin oleh peraturan perundang-undangan, alat bukti tersbut juga dapat dijadikan dasar atau alas hak untuk melakukan pendaftaran tanah agar dapat diterbitkan sertipikat hak atas tanah.

\footnotetext{
${ }^{15}$ Putusan Pengadilan Negeri Nomor : 138/Pdt.G/2014/PN/Smr., HIm. 3
} 
Kasus sengketa tanah ini selain terdapatnya alat bukti yang diajukan oleh pihak penggugat yakni surat penunjukan Walikota juga ada bukti kepemilikan hak atas tanah lain yang diberikan oleh pihak tergugat yakni telah terbitnya sertipikat hak milik (SHM) mengalami perubahan, yang dahulu Sertipikat Hak Milik Nomor 1147 Kelurahan Air Putih Kecamatan Samarinda, SU : 1988/1986 berubah menjadi Sertipikat Hak Milik Nomor 1134 Kelurahan Gunumg Kelua Kecamatan Samarinda Ulu Kota Samarinda, SU : 139/2010, NIB : 16010308.1.01980, dengan luas tanah tetap seluas 1.174 M²terletak dahulu jalan Pandan Harum sekarang jalan AW. Syahrani RT. XI Kelurahan Gunung Kelua, Kecamatan Samrina Ulu Kota Samarinda ${ }^{16}$. Berdasarkan data pencatatan peralihan hak pada sertipikat hak milik diketahui Tergugat III membeli tanah sengketa dari Tergugat II pada tanggal 9 April 1998, demikian pula Tergugat II membeli dari Tergugat I pada tanggal 11 Februari 1995. Bahwa oleh karena tanah obyek sengketa yang dimohonkan hak oleh Tergugat I adalah merupakan bagian dari tanah hak Penggugat yang diperoleh dari Penunjukan Walikota Samarinda tahun 1980. Dalam kasus ini, hakim menganggap sertipikat hak milik yang dimiliki oleh pihak tergugat lebih kuat kedudukannya sebagai alat bukti untuk membuktikan kepemilikan hak atas tanah.

Putusan hakim yang menolak gugatan penggugat dengan dalil bahwa surat penunjukan yang diajukan oleh penggugat tidak dapat dijadikan alat bukti kepemilikan hak atas tanah tersebut, putusan itu juga didasarkan karena pihak tergugat memiliki sertipikat hak atas tanah yang dikeluarkan oleh BPN pada tahn 2010. Sertipikat hak atas tanah yang diterbitkan oleh BPN tentulah memiliki kekuatan hukum, Badan Pertanahan Nasional ("BPN") merupakan lembaga yang salah satu fungsinya adalah melakukan perumusan dan pelaksanaan kebijakan di bidang penetapan hak tanah, pendaftaran tanah, dan pemberdayaan masyarakat. Sesuai dengan yang tercantum dalam Pasal 3 huruf c Peraturan Presiden No. 20 Tahun 2015 tentang Badan Pertanahan Nasional.

Sebelum BPN menerbitkan setfikat diatur dalam Pasal 19 ayat (2) Undang-Undang Nomor 5 Tahun 1960 tentang Peraturan Dasar Pokok-Pokok Agraria, pendaftaran tanah meliputi: Pengukuran, perpetaan dan pembukuan tanah; Pendaftaran hak-hak atas tanah dan peralihan hak-hak tersebut; Pemberian surat-surat tanda bukti hak, yang berlaku sebagai alat pembuktian yang kuat.

Proses terbitnya sertipikat harus juga dibuktikan dengan alas hak yang mampu menunjukan bahwa subyek tersebut memiliki hak terhadap tanah tersebut. Selain untuk memenuhi ketentuan undang-undang, pendaftaran tanah juga untuk memenuhi unsur publisitas dan kebaruan kepemilikan tanah oleh seseorang. Produk akhir dari rangkaian kegiatan pendaftaran tanah adalah diterbitkannya sertipikat hak atas tanah.Dari uraian di atas, maka tak ada lembaga pemerintahan lain yang memiliki kewenangan di bidang pertanahan, selain BPN.

Sacara yuridis tentu sertipikat yang dikeluarkan BPN lebih mempunyai kekuatan hukum. Namun, dalam sistem pendaftaran tanah di Indonesia, dikenal sistem pendaftaran negatif yang mengandung unsur positif. Dengan demikian, Negara tidak

\footnotetext{
${ }^{16}$ Putusan Pengadilan Negeri Nomor 138/Pdt.G/2014/PN.Smr, HIm. 5
} 
menjamin bahwa sertipikat yang disajikan sudah benar. Apabila ternyata di kemudian hari terdapat tuntutan atau gugatan dengan melampirkan bukti hak atas tanah yang lebih kuat, maka sertipikat yang sudah ada dapat dibatalkan karena salahnya dasar penerbitan sertipikat dimaksud.Namun, hal ini dikunci dengan adanya azas Rechtsverwerking, yaitu gugurnya hak untuk menuntut apabila seseorang sudah menguasai tanah dengan alas hak yang sah (bersertipikat), jika sudah lewat dari jangka waktu 5 (lima) tahun. Hal ini ditegaskan dalam Pasal 32 ayat (2) Peraturan PemerintahNomor 24 Tahun 1997 tentang Pendaftaran Tanah, yang berbunyi sebagai berikut"Dalam hal atas suatu bidang tanah sudah diterbitkan sertipikat secara sah atas nama orang atau badan hukum yang memperoleh tanah tersebut dengan itikad baik dan secara nyata menguasainya, maka pihak lain yang merasa mempunyai hak atas tanah itu tidak dapat lagi menuntut pelaksanaan hak tersebut apabila dalam waktu 5 (lima) tahun sejak diterbitkannya sertipikat itu tidak mengajukan keberatan secara tertulis kepada pemegang sertipikat dan Kepala Kantor Pertanahan yang bersangkutan ataupun tidak mengajukan gugatan ke Pengadilan mengenai penguasaan tanah atau penerbitan sertipikat tersebut".

Dari penjelasan diatas dapat kita analisis bahwa sertipikat merupakan bukti kepemilikan hak atas tanah yang kuat, namun tidaklah menjadi bukti yang mutlak tidak dapat digugat selama tidak lebih dari waktu 5 (lima) tahun sejak sertipikat itu diterbitkan. Artinya sertipikat itu dapat kemudian digugat apabila dalam proses penerbitannya terdapat kesalahan proseduran atau terjadi cacat administrasi, yang kemudian dapat dibuktikan dengan alat bukti lainnya yang menjadi alas hak yang kuat untuk membuktikannya.

Pihak penggugat melakukan gugatan atas sertipikat tanah yang dikeluarkan BPN dengan Nomor 1134 Kelurahan Gunumg Kelua Kecamatan Samarinda Ulu Kota Samarinda, SU: 139/2010, sertipikat ini dikeluarkan oleh BPN pada tahun 2010 yang digugat pada tahun 2010 oleh pihak ahli waris yang memiliki bukti surat penunjukan Walikota Samarinda tanggal 18 November 1980 Nomor 48/SP/Komas/1980 dengan lampiran Gambar Situasi (GS) Nomor 1543/K/80 tanggal 23 September 1980. Sesuai dengan Pasal 32 Ayat (2) Peraturan Pemerintah Nomor 24 Tahun 1997 tentang Pendaftaran Tanah maka pihak penggugat melakukan gugatan tidak lebih dari 5 tahun, dan hal itu secara okum dapat dilakukan.

Surat penunjukan oleh Pemerintah/Pemerintah Daerah merupakan alat bukti yang diakuin oleh Pasal 24 Ayat (1) Peraturan Pemerintah Nomor 24 Tahun 1997 tentang Pendaftaran Tanah, dan surat penunjukan yang dijadikan alat bukti oleh penggugat merupakan surat penunjukan untuk menggantian tanah pihak penggugat karena terjadi perluasan Unmul, artinya surat penunjukan tersebut terbit karena proses yang jelas dan dalam hal ganti rugi tanah oleh pemerintah ganti rugi tersebut diakuin bahwa dapat dilakukan dengan memberikan tanah pengganti. Surat penunjukan itu menjadi alas hak yang paling lama dipegang oleh penggugat.

Putusan hakim Pengadilan Negeri Samarinda Nomor 138/Pdt.G/2014/PN.Smr tidaklah tepat dan tidak memberikan kepastian hukum, hal itu disebabkan oleh tidak dijadikan rujukan apa yang termuat dalam Pasal 24 ayat (1) dan Pasal 32 ayat (2) Peraturan 
Pemerintah Nomor 24 Tahun 1997 tentang Pendaftaran Tanah. Surat penunjukan sebagai alat bukti dapat kita temukan dalam Peraturan Pemerintah Nomor 24 Tahun 1997 tentang Pendaftaran Tanah, dalam Pasal 24 ayat (1) disebutkan bahwa "Untuk keperluan pendaftaran hak, hak atas tanah yang berasal dari konversi hak-hak lama dibuktikan dengan alat-alat bukti mengenai adanya hak tersebut berupa bukti-bukti tertulis, keterangan saksi dan atau pernyataan yang bersangkutan yang kadar kebenarannya oleh Panitia Ajudikasi dalam pendaftaran tanah secara sistematik atau oleh Kepala Kantor Pertanahan dalam pendaftaran tanah secara sporadik, dianggap cukup untuk mendaftar hak, pemegang hak dan hak-hak pihak lain yang membebaninya".

Kemudian dalam bagian penjelasan Pasal 24 ayat (1) tersebut dirincikan alat bukti tersebut dapat berupa surat penunjukan atau pembelian kaveling tanah pengganti tanah yang diambil oleh Pemerintah atau Pemerintah Daerah. Artinya dapat kita analisa bahwa surat penunjukan yang kemudian dikeluarkan oleh pemerintah atau pemerintah dasar merupakan alat bukti atas kepemilikan tanah yang sah dan diakuin oleh peraturan perundang-undangan, alat bukti tersbut juga dapat dijadikan dasar atau alas hak untuk melakukan pendaftaran tanah agar dapat diterbitkan sertipikat hak atas tanah. Kasus sengketa tanah ini selain terdapatnya alat bukti yang diajukan oleh pihak penggugat yakni surat penunjukan Walikota juga ada bukti kepemilikan hak atas tanah lain yang diberikan oleh pihak tergugat yakni telah terbitnya sertipikat hak milik (SHM) mengalami perubahan, yang dahulu Sertipikat Hak Milik Nomor 1147 Kelurahan Air Putih Kecamatan Samarinda, SU : 1988/1986 berubah menjadi Sertipikat Hak Milik Nomor 1134 Kelurahan Gunumg Kelua Kecamatan Samarinda Ulu Kota Samarinda, SU : 139/2010, NIB : 16010308.1.01980, dengan luas tanah tetap seluas $1.174 \mathrm{M}^{2}$ terletak dahulu jalan Pandan Harum sekarang jalan AW. Syahrani RT. XI Kelurahan Gunung Kelua, Kecamatan Samrina Ulu Kota Samarinda .

Berdasarkan data pencatatan peralihan hak pada sertipikat hak milik diketahui Tergugat III membeli tanah sengketa dari Tergugat II pada tanggal 9 April 1998, demikian pula Tergugat II membeli dari Tergugat I pada tanggal 11 Februari 1995. Bahwa oleh karena tanah obyek sengketa yang dimohonkan hak oleh Tergugat I adalah merupakan bagian dari tanah hak Penggugat yang diperoleh dari Penunjukan Walikota Samarinda tahun 1980. Dalam kasus ini, hakim menganggap sertipikat hak milik yang dimiliki oleh pihak tergugat lebih kuat kedudukannya sebagai alat bukti untuk membuktikan kepemilikan hak atas tanah.

\section{CONCLUSION}

Secara hukum kedudukan hukum ahli waris dalam pembuktian hak atas tanah haruslah didasarkan terlebih dahulu melalui surat keterangan waris. Untuk menguatkan pembuktian ahli waris terhadap hak atas tanah tersebut maka ahli waris harus membuktikan dengan alat bukti sebagaimana yang telah diatur dalam bagian penjelasan Pasal 24 ayat (1) Peraturan Pemerintah Nomor 24 Tahun 1997 tentang Pendaftaran, pembuktian yang diatur menurut hukum agraria sebagai penguat untuk dapat melakukan pembuktian hak atas tanah secara hukum perdata, yakni dengan alat bukti tertulis/tulisan. 
Berdasarkan Surat Penunjukan dari Walikotamadya Kepala Daerah Tingkat II Samarinda sekarang disebut Walikota Samarinda Nomor 48/SP/Komas/1980, surat ini menjadi alat bukti sebagai alas hak paling lama atas tanah obyek sengketa, yang diakuin oleh hukum Indonesia. Pada Pasal 32 ayat (2) dapat dilakukan gugatan atas seritifkat hak atas tanah selama tidak lebih dari 5 (lima) tahun sejak sertipikat itu diterbitkan. putusan hakim Pengadilan Negeri Samarinda Nomor 138/Pdt.G/2014/PN.Smr tidaklah tepat dan tidak memberikan kepastian hukum, hal itu disebabkan oleh tidak dijadikan rujukan apa yang termuat dalam Pasal 24 ayat (1) dan Pasal 32 ayat (2) Peraturan Pemerintah Nomor 24 Tahun 1997 tentang Pendaftaran Tanah.

\section{REFERENCES}

Hasan Kusumah, 1995, Hukum Agraria I, Gramedia Pustaka Utama. Jakarta,

Mertokusumo Sudikno, 2006, Hukum Acara Perdata Indonesia, Liberty Yokyakarta, halaman 161Syahrani Riduan, 1998, Hukum Acara Perdata Dilingkungan Peradilan Umum, Pustaka Kartini, Jakarta,

Peter Mahmud Marzuki, 2010, penelitian hukum, PT Kencana, Jakarta

Retnowulan S Dan Iskandar O, 2005, Hukum Acara Perdata, P.T Intermasa cet. XXXII, Jakarta,

R. Subekti, S.H. dan R. Tjitrosudibio., 2008. kitab Undang-Undang Hukum Perdata., PradnyaParamita, Jakarta.

R. Subekti, 1995, Hukum Pembuktian, PT. Pradnya Paramita.

Sudikno Martokusumo, 2016, Hukum Acara Perdata Indonesia Edisi Ke 7, Liberti Cet.I, Yokyakarta, halaman 134

Urip Santoso. 2010, Pendaftaran dan Peralihan Hak atas Tanah., Prenada Media Group, Jakarta, cetakan ke-2, hal 248.

RM Pramana, 2014. Analisis Yuridis Surat Keterangan Waris Sebagai Alat Bukti. studentjournal.ub.ac.id. https://media.neliti.com/media/publications/34936-IDanalisis-yuridis-surat-keterangan-waris-sebagai-alat-bukti.pdf . Di akses 8 Juni 2018, pk. 11.34 Wite 